\title{
Phytochemical and Antioxidant Analyses of Selected Edible Mushrooms, Ginger and Garlic from Ebonyi State, Nigeria.
}

\author{
Udu-Ibiam, O. E. ${ }^{1}$, Ogbu, O. ${ }^{1}$, Ibiam, U. A. ${ }^{2}$, Nnachi, A. U. ${ }^{3}$, Agah, M. V. ${ }^{1}$, \\ Ukaegbu, C. O. ${ }^{4}$, Chukwu, O.S. ${ }^{5}$, Agumah, N. B. ${ }^{1}$, Ogbu, K. I. ${ }^{6}$ \\ ${ }^{1}$ Department of Applied Microbiology, Faculty of Biological Sciences, Ebonyi State University, Abakaliki \\ ${ }^{2}$ Department of Biochemistry, Faculty of Biological Sciences, Ebonyi State University, Abakaliki, Nigeria \\ ${ }^{3}$ Department of Medical Microbiology and Parasitology, Faculty of Medicine, Nnamdi Azikiwe University,Awka \\ ${ }^{4}$ Department of Microbiology, Faculty of Natural Sciences, University of Jos, Jos, Nigeria \\ ${ }^{5}$ Deparment of Biology, Microbiology and Biotechnology, Federal University, Ndufu-Alike, Ikwo, Nigeria \\ ${ }^{6}$ Department of Biotechnology, Ebonyi State University, Abakaliki, Nigeria
}

\begin{abstract}
Antioxidant defense and repair systems naturally found in humans as well as in other living organisms are insufficient to completely prevent biological injuries caused by free radicals because of the relative ease with which we are constantly exposed to processes that generate them. The advantage of dietary antioxidants over synthetic ones (which are associated with gross side effects) as free radical scavengers has been documented worldwide. In this study, the phytochemical and antioxidant analyses of selected edible mushrooms, ginger and garlic from Ebonyi State, Nigeria, were carried out using dried extracts of the samples. The results revealed the presence of valuable phytochemicals including: phenolics, flavonoid, proanthocyanidin, saponin, alkaloid, tannin, phytic acid, and cyanogenic glycosides. Ginger (Zingiber officianale) had the highest phenolics content of $64.42 \pm 0.91 \mathrm{mg} / \mathrm{g}$, closely followed by the mushroom, Tricholoma nudum, $(64.122 \pm 1.20)$ and garlic (Allium sativum) $(12.42 \pm 0.61 \mathrm{mg} / \mathrm{g})$. Least phenolics content of $2.65 \pm 0.006 \mathrm{mg} / \mathrm{g}$ was observed in the study with the mushroom, Boletus spp. Ginger also had the highest flavonoid content of $0.045 \pm 0.001 \mu \mathrm{g} / \mathrm{g}$. The presence of these bioactive or phytochemical compounds supports the possible antimicrobial and antioxidant potentials of mushrooms, ginger and garlic and high phenolics and flavonoid contents of ginger and mushroom suggests high antioxidant potentials.
\end{abstract}

Keywords: Antioxidants, Garlic (Allium sativum), Ginger (Zingiber officianale), Mushrooms, Nigeria Phytochemicals

\section{Introduction}

Edible mushrooms have gained worldwide recognition and increasing popularity owing to their nutritional and medicinal values since Greek and Roman antiquity. ${ }^{[1],[2]}$ They are macroscopic fungi with distinctive fruiting bodies which can be hypogeous or epigeous, large enough to be seen with unaided eyes and to be picked by hands. ${ }^{[3]}$ Mushrooms, divided into edible and poisonous types, grow in various places such as wet environments, decayed plants and animal sites, termites' nests, palm wastes, leaf litters, under shades, to mention but a few. ${ }^{[4]}$

Herbs and spices (including ginger and garlic) are very important and useful as therapeutic agents against many pathological conditions. ${ }^{[5]}$ Spices have been defined as plant substances from indigenous or exotic origin, aromatic or with strong taste used to enhance tastes of foods ${ }^{[6]}$ Ginger (Zingiber officianale) is a rhizoid white to yellow in colour and very aromatic with lots of beneficial uses. ${ }^{[7]}$ Garlic (Allium sativum) is a species of onion; it possesses characteristic hot, pungent flavor and has been know down history to be used for both culinary and medical purposes. ${ }^{[8]}$

Besides nutritional and medicinal values, mushrooms, ginger and garlic have been shown to have antioxidant potentials. ${ }^{[6],[9]-[12]}$ Antioxidants are molecules that can neutralize free radicals by accepting or donating an electron to eliminate unpaired condition of electrons thereby protecting the body from damages caused by free radicals. ${ }^{[13]}$ These free radicals are independent chemicals with one or more unpaired electrons and are responsible for biological injury ${ }^{[14]}$ and contribute to many non-communicable diseases. ${ }^{[2]}$ They are constantly formed in human body during energy production, in the mitochondrial electron transport chain, phagocytosis, arachidonic acid metabolism, ovulation, fertilization and in xenobiotic metabolism ${ }^{[15]}$ and from external sources such as food, drug, smoke and other pollutants in the environment, ${ }^{[12]}$ making them constant threats to human well being.

Naturally, humans as well as other living organisms are endowed with antioxidant defense and repair systems are insufficient to completely prevent oxidative damage, considering the relative ease with which we are daily exposed to processes that generate them. ${ }^{[16]}$ Hence, there is constant need for external aids to these systems if we must be free of the damages caused by free radicals. Most available synthetic antioxidants which 
act as free radical scavengers are associated with gross side effects, ${ }^{[1]]}$ making the need for natural and safe antioxidants sources even greater. Polyphenols and other phytochemicals have been shown to have antioxidant activities; it has then been suggested that consumption of polyphenol-rich foods is associated with a reduced risk of cardiovascular diseases, stroke and certain types of cancer. ${ }^{[18],[19]}$ The consumption of dietary antioxidants would help to prevent free radical oxidative damage ${ }^{[2]}$ by inhibiting the initiation step or interrupting the propagation step of oxidation damage. ${ }^{[20]}$

Although the antimicrobial activities of edible mushrooms, ginger and garlic have been increasingly researched upon, analysis of their antioxidant importance has received insignificant attention. The present study, therefore, was carried out to determine the phytochemical and antioxidant potentials of extracts of mushrooms, ginger and garlic from Ebonyi State, Nigeria.

\subsection{Collection and Identification of Materials}

\section{Materials And Methods}

Five species of mushroom including Tricholoma nudum, Psalliota campestris, Flammulina sp, Trichaptum sp, and Boletus sp, were collected from different parts of Egugwu, Umuchima and Umunaga all in Uburu, Ohaozara Local Government Area of Ebonyi State, Nigeria.The garlic and ginger used were bought from Abakpa Market in Abakaliki, Ebonyi State, Nigeria. All chemicals used for various analyses were purchased from Aldrich chemicals, Poole, UK.

\subsection{Extraction of Mushroom, Ginger and Garlic}

The extraction was carried out in accordance with the procedure of Fasidi and Jonathan. ${ }^{[21]}$ The respective mushroom, ginger and garlic samples were cut into bits and sun dried for 6 days and then pulverised into powder using manual grinder. $40 \mathrm{~g}$ of each of the pulverised mushroom were respectively weighed and soaked in $200 \mathrm{ml}$ of cold water, hot water, and ethanol. The ginger and garlic were soaked in $200 \mathrm{ml}$ of cold water only. Cold water preparation was allowed to stand for 2 days only with intermittent shakings at 30 minutes intervals (this is to prevent mold from growing in the extraction water). The hot water was allowed to stand for $24 \mathrm{hrs}$ (same reason as above). The ethanol and diethyl ether were allowed to stand for 7 days. Then the four preparations were filtered using Whatman filter paper no 1 . The filtrate was poured in crucible and air dried at room temperature to recover extracts.

\subsection{Quantitative Determination of Phytochemicals}

The following phytochemicals were quantitatively determined in the mushrooms, ginger and garlic extracts: Phytic acid, tannin, alkaloids, saponin, flavonoid, phenolics, proanthocyanidins, and cyanogenic glycoside.

\subsubsection{Phytic Acids (Phytate) Determination}

The method adopted was as described by Harbone. ${ }^{[22]}$ Briefly, the plant material (mushroom, ginger and garlic) was extracted. Solution was made up to give up to 3-30 mgml- ${ }^{1}$ phytate solution. $0.5 \mathrm{ml} \mathrm{of} \mathrm{extract}$ was pipetted into a test tube filled with a ground glass stopper. On it $1 \mathrm{ml}$ of Ferric solution was added, the tube was covered with the stopper and fixed with a clip. The tube was heated in a boiling water bath for 30 minutes. Within the first 5 minutes, care was taken that the tube remained well stoppered. The set up was covered in ice water for 15 minutes. It was then allowed to adjust to room temperature. Once the tube has reached room temperature, about $2 \mathrm{ml}$ of 2, 2-Bipyridine solution was added to the test tube and mixed. The bipyridine reacted with the iron phytate and the color changed with time. The absorbance was measured after about $0.5-1 \mathrm{~min}$ at $519 \mathrm{~nm}$ against distilled water.

\subsubsection{Determination of Tannins}

The method used was according to that described by Maga. ${ }^{[23]}$ A measured weight of each sample (1.0 g) was dispersed in $10 \mathrm{ml}$ of distilled water and agitated. This was left to stand for 30 minutes at room temperature, being shaken every 5 minutes. At the end of the 30 minutes, it was centrifuged and the supernatant decanted. $2.5 \mathrm{ml}$ of the supernatant extract was dispensed into $50 \mathrm{ml}$ volumetric flask. Similarly $2.5 \mathrm{ml}$ of standard tannic acid solution was dispensed into a separate $50 \mathrm{ml}$ flask. A $1.0 \mathrm{ml}$ Folin-Denis reagent was measured into each flask followed by $2.5 \mathrm{ml}$ of saturated $\mathrm{Na}_{2} \mathrm{CO}_{3}$ solution. The mixture was diluted to $50 \mathrm{ml}$ mark in the flask, and incubated for 90 minutes at room temperature. The absorbance was measured at $250 \mathrm{~nm}$ in a Genway model 6000 electronic spectrophotometer. Readings were taken with the reagent blank at zero. The tannin content was calculated as follows:

$\%$ Tannin $=[(\mathrm{An} / \mathrm{As}) \mathrm{x}(\mathrm{C} \times 100)] /[\mathrm{W} \times(\mathrm{Vf} / \mathrm{Va})]$

Where An $=$ absorbance of test sample

As $=$ absorbance of standard solution 
$\mathrm{C}$ = concentration of standard solution

$\mathrm{W}=$ weight of sample used

$\mathrm{Vf}=$ total volume of extract

$\mathrm{Va}=$ volume of extract analyzed

\subsubsection{Determination of Alkaloids}

The gravimetric methods of Harbone ${ }^{[22]}$ were adopted. A given weight (5.0) of each sample was weighed out and dispersed into $50 \mathrm{ml}$ of $10 \%$ acetic acid solution in ethanol. The mixture was well shaken and allowed to stand for 4 hours before filtering. The filtrate was evaporated to one quarter (1/4) of its original volume. Then a concentrated $\mathrm{NH}_{4} \mathrm{OH}$ was added drop-wise to precipitate the alkaloids. The precipitate was filtered off with a weighed filter paper. The precipitate in filter paper was dried in an oven at $60^{\circ} \mathrm{C}$ for 30 minutes and reweighed. The weight of alkaloids is normally determined by weight difference.

The percentage alkaloids were calculated thus:

Percentage Alkaloids $=W_{2}-W_{2} \times 100$

Where $\mathrm{W}=$ weight of samp'

$\mathrm{W}_{1}=$ weight of empty filter $\mathrm{W}$

$\mathrm{W}_{2}=$ weight of paper plus precipitate

\subsubsection{Determination of Saponin}

The spectrophometric method of Brunner ${ }^{[24]}$ was used for saponin analysis. Exactly I g of finely ground sample was weighed into a $250 \mathrm{ml}$ beaker and $100 \mathrm{ml}$ of ethyl alcohol was added. The mixture was shaken on a UDY shaker for 5 hours to ensure uniform mixing. Thereafter, the mixture was filtered through a Whatman No. I filter paper into a $100 \mathrm{ml}$ beaker and $20 \mathrm{ml}$ of $40 \%$ saturated solution of $\mathrm{MgCO}_{3}$ was added. The mixture obtained with saturated $\mathrm{MgCO}_{3}$ was again filtered through a Whatman No 1 filter paper to obtain a clear colorless solution. About I $\mathrm{ml}$ of the colorless solution was pipetted into $50 \mathrm{ml}$ volumetric flask containing $5 \% \mathrm{FeCl}_{3}$ solution and made up to mark with distilled water. It was allowed to stand for 30 minutes. 0-10 ppm standard saponin was prepared from saponin stock solution. The standard solutions were treated similarly with 2 $\mathrm{ml}$ of $5 \% \mathrm{FeCl}_{3}$ solution as done for $1 \mathrm{ml}$ sample above. The absorbances of the sample as well as standard saponin solution were read after colour development on an Agilient spectrophometer at a wavelength of $380 \mathrm{~nm}$. Calculation:

Saponin $(\mathrm{ppm})=$

Absorbance of sample $\mathrm{x}$ Gradient factor x dilution factor

\subsubsection{Determination of Flavonoids Weight of sample}

Aluminum chloride colorimetric method was used for flavonoid determination based on Chang et al.

${ }^{[25]}$ Each plant extracts $(0.5 \mathrm{ml}$ of $1: 10 \mathrm{~g} / \mathrm{ml})$ in method were separately mixed with $1.5 \mathrm{ml}$ of methanol, $0.1 \mathrm{ml}$ of $10 \%$ Aluminum chloride, $0.1 \mathrm{ml}$ of $1 \mathrm{ml}$ of potassium acetate and $2.8 \mathrm{ml}$ of distilled water. It remained at room temperature for 30 minutes; the absorbance of the reaction mixture was measured at $413 \mathrm{~nm}$ with a 6405 $\mathrm{UV} / \mathrm{visible} \mathrm{spectrophotometer.}$

\subsubsection{Determination of Phenolics}

The total phenolics were determined using spectrophotometric method described by Brunner. ${ }^{[2]}$ To each test tube containing $10 \mathrm{ml}$ of $50 \%$ aqueous ethanol, $30 \mathrm{~g}$ of dry finely ground mushroom and spice was added and extracted for two hour by shaking every 15 minutes using vortex. $200 \mathrm{ml}$ of initial extract was added to a $50 \mathrm{ml}$ volumetric flask containing about $25 \mathrm{ml}$ of water. At time zero, $2.5 \mathrm{ml}$ of Folin-Denise reagent was added and mixed well. After 3 minutes, $5 \mathrm{ml}$ of saturated sodium carbonate was added and brought to volume with water and then mixed well. After exactly 20 minutes, the absorbance was measured at 760nm.

\subsubsection{Determination of Proanthocyanidin}

The total proanthocyanidin was determined according to Maga. ${ }^{[23]}$ To a test tube, $1.0 \mathrm{ml}$ of initial extract $30 \mathrm{mg}$ of finely ground sample material in $10 \mathrm{ml}$ of $50 \%$ aqueous ethanol) was added. $1.0 \mathrm{ml}$ of $\mathrm{n}$ butanol- $\mathrm{HCl}$ reagent was added and mixed well using a vortex. It was then placed on a dry bath at $100^{\circ} \mathrm{C}$ for 1 hour. It was allowed to cool to room temperature and the absorbance was measured at $550 \mathrm{~nm}$.

\subsubsection{Determination of Cyanogenic Glycosides}

The alkaline picrate method was used according to Harbone. ${ }^{[22]}$ Briefly, about $5.0 \mathrm{~g}$ of the sample was ground to paste. The paste was dissolved in $50 \mathrm{ml}$ distilled water in a corked conical flask and allowed to stay overnight. The extract was filtered and the filtrate used for the cyanide determination. Alkaline picrate solution 
was prepared by dissolving $1 \mathrm{~g}$ picrate and $5 \mathrm{~g}$ sodium carbonate in a volume of minimally warm water and then made up to $200 \mathrm{ml}$ with distilled water. Exactly $1 \mathrm{ml}$ of sample filtrate was put in a test and corked firmly. This was followed by addition of $4 \mathrm{ml}$ of alkaline picrate and incubated in a water bath for 5 minutes. After colour development (reddish brown colour), the absorbance read at $490 \mathrm{~nm}$ using a Spectrophotometer against a blank solution which contained only $1 \mathrm{ml}$ distilled water and $4 \mathrm{ml}$ alkaline picrate solution.

\section{Results}

The study showed that the extracts of mushrooms, ginger and garlic contained that following phytochemicals, though in varying proportions: phenolics, flavonoid, proanthocyanidin, saponin, alkaloid, tannin, phytic acid and cyanogenic glycosides. Ginger (Zingiber officianale) had the highest phenolics content of $64.42 \pm 0.91 \mathrm{mg} / \mathrm{g}$, closely followed by the mushroom, Tricholoma nudum, (64.122 \pm 1.20$)$ and garlic (Allium sativum) $(12.42 \pm 0.61 \mathrm{mg} / \mathrm{g})$. Least phenolics content of $2.65 \pm 0.006 \mathrm{mg} / \mathrm{g}$ was observed in the study with the mushroom, Boletus spp. Ginger also had the highest flavonoid content of $0.045 \pm 0.001 \mu \mathrm{g} / \mathrm{g}$, followed by Psalliota compestris $(0.031 \pm 0.02 \mu \mathrm{g} / \mathrm{g})$ and then Flammulina spp. $(0.0199 \pm 0.003 \mu \mathrm{g} / \mathrm{g})$. Garlic had the least flavonoid content of $(0.0021 \pm 0.0002 \mu \mathrm{g} / \mathrm{g})$. Highest contents of proanthocyanidin $(10.82 \pm 0.14 \mathrm{mg} / \mathrm{g})$, saponin $(5.13 \pm 0.05 \mu \mathrm{g} / \mathrm{g})$, alkaloid $(3.01 \pm 0.01 \%)$, tannins $(0.014 \pm 0.003 \%)$, phytic acid $(0.821 \pm 0.021 \%)$ and Cyanogenic glycosides (259.57 \pm 1.11$)$ were observed with ginger, Boletus spp., Trichaptum spp., Tricholoma nudum, $P$. compestris and $P$. compestris respectively. Details of the results are shown in the following TABLE 1 .

Table 1: Phytochemical contents of selected edible mushrooms, ginger and garlic from Ebonyi State,

Nigeria.

\begin{tabular}{|c|c|c|c|c|c|c|c|c|}
\hline \multirow[t]{2}{*}{ Extract } & \multicolumn{8}{|c|}{ Proportion of Phytochemicals Present } \\
\hline & $\begin{array}{c}\text { Phenolic } \\
\mathrm{s} \\
(\mathrm{mg} / \mathrm{g})\end{array}$ & $\begin{array}{c}\text { Flavonoid } \\
(-\mathrm{g} / \mathrm{g})\end{array}$ & $\begin{array}{c}\text { Proanthocya } \\
\text { nidin } \\
(\mathrm{mg} / \mathrm{g})\end{array}$ & $\begin{array}{l}\text { Saponin } \\
(\square g / g)\end{array}$ & $\begin{array}{c}\text { Alkaloid } \\
(\%)\end{array}$ & $\begin{array}{c}\text { Tannins } \\
(\%)\end{array}$ & $\begin{array}{c}\text { Phytic } \\
\text { acid }(\%)\end{array}$ & $\begin{array}{c}\text { Cyanoge } \\
\text { nic } \\
\text { glycosid } \\
\text { es }\end{array}$ \\
\hline $\begin{array}{l}\text { Trichol } \\
\text { ina } \\
\text { yudum }\end{array}$ & $\begin{array}{c}64.122=1 \\
.2\end{array}$ & $\begin{array}{c}0.0164=0 \\
001\end{array}$ & $4.41=0.24$ & $0.28 \pm 0.04$ & $1.0 \pm 0.04$ & $\begin{array}{c}0.014=0.0 \\
03\end{array}$ & $\begin{array}{c}0.21=0.0 \\
3\end{array}$ & $\begin{array}{c}130.69=0 \\
.04\end{array}$ \\
\hline $\begin{array}{l}\text { Psalliot } \\
\text { d } \\
\text { dompest } \\
\text { ris }\end{array}$ & $\begin{array}{c}6.012=0 \\
91\end{array}$ & $\begin{array}{c}0.031=0.0 \\
2\end{array}$ & $6.015=0.31$ & $0.27=0.008$ & $2.0=0.01$ & $0.014=0.0$ & $\begin{array}{c}0.821=0 . \\
021\end{array}$ & $\begin{array}{c}259.57=1 \\
.11\end{array}$ \\
\hline $\begin{array}{l}\text { Flammu } \\
\text { lina } \\
\text { spp. }\end{array}$ & $\begin{array}{c}4.81=0.0 \\
9\end{array}$ & $\begin{array}{c}0.0199=0 . \\
003\end{array}$ & $10.02=0.05$ & $0.27=0.006$ & $0.2=0.01$ & $\begin{array}{c}0.011=0.0 \\
04\end{array}$ & $\begin{array}{c}0.093=0 . \\
04\end{array}$ & $\begin{array}{c}177.67=1 \\
.21\end{array}$ \\
\hline $\begin{array}{l}\text { Trichap } \\
\text { tum spp. }\end{array}$ & $\begin{array}{c}4.41=0.5 \\
1\end{array}$ & $\begin{array}{c}0.0174=0 \\
001\end{array}$ & $8.42=0.21$ & $4.82=0.05$ & $3.01=0.01$ & $\begin{array}{c}0.0114=0 . \\
002\end{array}$ & $\begin{array}{c}0.162=0 . \\
02\end{array}$ & $\begin{array}{c}115.28=0 \\
.59\end{array}$ \\
\hline $\begin{array}{l}\text { Boletus } \\
\text { spp. }\end{array}$ & $\begin{array}{c}2.65=0.0 \\
6\end{array}$ & $\begin{array}{c}0.0164=0 \\
004\end{array}$ & $3.61=0.11$ & $5.13=0.05$ & $0.1=0.003$ & $\begin{array}{c}0.013=0.0 \\
03\end{array}$ & $\begin{array}{c}0.162=0 . \\
02\end{array}$ & $\begin{array}{c}24.13=0 \\
92\end{array}$ \\
\hline $\begin{array}{l}\text { Ginger } \\
\text { (Zingibe } \\
r \\
\text { dffician } \\
\text { cle) }\end{array}$ & $\begin{array}{c}64.42=0 . \\
91\end{array}$ & $\begin{array}{c}0.045=0.0 \\
01\end{array}$ & $10.82=0.14$ & $4.96=0.06$ & $2.0=0.02$ & $\begin{array}{c}0.0059=0 . \\
0\end{array}$ & $\begin{array}{c}0.394=0 . \\
021\end{array}$ & $\begin{array}{c}103.73=0 \\
.92\end{array}$ \\
\hline $\begin{array}{l}\text { Garlic } \\
\text { (Allium } \\
\text { sativum }\end{array}$ & $\begin{array}{c}12.424=0 \\
.61\end{array}$ & $\begin{array}{c}0.0021=0 \\
0002\end{array}$ & $2.004=0.05$ & $0.587=0.02$ & $3.0=0.022$ & $\begin{array}{c}0.0008=0 . \\
0004\end{array}$ & $\begin{array}{c}0.232=0 \\
09\end{array}$ & $\begin{array}{c}33.38=0 \\
58\end{array}$ \\
\hline
\end{tabular}

\section{Discussion}

The results of the phytochemical analyses of some selected edible mushrooms (Tricholoma nudum, Psalliota compestris, Flammulina spp., Trichaptum spp.), ginger and garlic from Ebonyi State, Nigeria, revealed the presence of phenolics, flavonoid, proanthocyanidin, saponin, alkaloid, tannins, phytic acid and cyanogenic glycosides, though in varying concentrations. These phytochemicals play a vital role in the medicinal properties of many plants. Spices are rich sources of polyphenolic compounds having strong antioxidant capacities and could potentially replace the synthetic antioxidants in food systems and offer additional health benefits. Consumption of spices has been implicated in the prevention of many chronic diseases such as cardiovascular diseases, cancer and inflammation. ${ }^{[2]}$ The results are in agreement with several previous works of Hamzah et $a l .{ }^{[12]}$ and Egwim et al. ${ }^{[11]}$ both in Minna, Nigeria, Ehssan and Saadabi ${ }^{[27]}$ in Sudan, Panpatil et al. ${ }^{[26]}$ in India as 
well as Wandati et al. ${ }^{[28]}$ in Kenya who independently detected these phytochemicals in their studies. However, Iwalokun et al. ${ }^{[29]}$ in Lagos, Nigeria and Mattila et al. ${ }^{[30]}$ did not detect flavonoid in their study. The variation in these results could be attributed to the species of mushrooms under study as well as the variations in their growth conditions since they did not grow in the same place. Studies have shown that the absence of flavonoid in mushrooms may be of biological advantage in their various ecological niches. ${ }^{[31]}$

Ginger and the mushroom, T. nudum, showed very high contents of total phenolics, followed by garlic, possibly making them better antioxidants than garlic and the other species of mushrooms. The low and varied concentrations of these phytochemicals among the tested mushrooms may be attributed to mycelia wet and wet weights. Phenolics are good antioxidants and exhibit a wide range of pharmacological properties such as anticancer, anti-inflammatory and anti-diabetic effects. ${ }^{[32],[33]}$ Flavonoids are group of more than 4000 polyphenolic compounds that occur naturally in food of plant origin, possessing a number of beneficial effects to human health. ${ }^{[34]}$ They are potent water-soluble super antioxidants and free radical scavengers that prevent oxidative damage, and have anti-cancer, anti-inflammatory, anti-allergic, antiviral, vasodilating properties and inhibition of platelet aggregation. ${ }^{[12],[34],[35]}$ The large quantities of flavonoid observed in ginger against mushrooms and garlic is in conformity with the work of Atai et al. ${ }^{[36]}$

Also, it is known that Saponins inhibit $\mathrm{Na}+$ efflux by blockage of the influx of concentration in the cells, activating a $\mathrm{Na}^{+}-\mathrm{Ca}^{2+}$ antiporter in cardiac muscles. The increase in $\mathrm{Ca}^{2+}$ influx through this antiporter strengthens the contraction of cardiac muscles. ${ }^{[10],[37]}$ They are as well reported to have antibacterial, antihaemolytic, anti-diabetic, anti-inflammatory and cholesterol-binding properties. ${ }^{[34],[38]}$ Tannins may elicit antibacterial activities via cell membrane lysis, inhibition of protein synthesis, proteolytic enzymes and microbial adhesions. ${ }^{[39]}$ They are also reported to have physiological effects like anti-irritant, anti-secretolytic and anti-parasitic effects. Plants containing tannins are used to treat non specific diarrhea and inflammation of the mouth. ${ }^{[40],[41]}$ The rich tannin content of Trichaptum species observed in this study is in collaboration with the work of Westerndarp ${ }^{[40]}$.

Proanthocyanidin inhibits lipid peroxidation, platelet aggregation, capillary permeability and bacterial fragility. ${ }^{[42]}$ The value of proanthocyanidin is higher in ginger than in mushrooms. The valuable pharmacological properties of mushrooms, ginger and garlic have been attributed to the presence of alkaloids on the autonomic nervous system, blood vessels, respiratory system, gastrointestinal tract, uterus and it has been shown to be effective against malignant diseases and malaria. ${ }^{[12]}$ In ophthalmology, it acts as anaesthesia, pain reliever, antipuretic action among others.

Steroids and anthraquinones were not detected in this study. This correlates with the previous works of Egwim et al. ${ }^{[10]}$ The absence of steroids does not agree with the findings of Hamzah et al. ${ }^{[12]}$ while the absence of anthraquinones disagrees with the results of Akindahunsi ${ }^{[43]}$ and Schneider and Wolfling ${ }^{[37]}$.

\section{Conclusion}

This study has further elaborated our knowledge of medicinal and health benefits of mushrooms, ginger and garlic. The presence of the phytochemicals in the tested materials could possibly account for these benefits. Also observed is the fact that mushrooms and ginger could be better antioxidants than garlic because of their high phenolics and flavonoid contents. It is therefore, recommended that ginger, mushrooms and garlic be properly harnessed in the management and treatment of oxidative stress induced conditions, bacterial and viral diseases, cancer, diabetes, allergy, platelet aggregation, arthritis, asthma, atherosclerosis and used as blood cleansers and warm expellants. ${ }^{[44],[45]}$

\section{References}

[1]. H. Pushpa and K. B. Purushothama, Antimicrobial Activity of Lyophyllum decastes an Edible Wild Mushroom, World Journal of Agricultural Sciences, 6(5), 2010, 506-509.

[2]. C. H. Gan, B. Nurul-Amira and R. Asmah, Antioxidant analysis of different types of edible mushrooms (Agaricus bisporous and Agaricus brasiliensis), International Food Research Journal 20(3), 2013, 1095-1102.

[3]. S. T. Chang, P. G. Miles. - Mushrooms Cultivation, Nutritional Value, Medicinal Effect, and Environmental Impactll. 2nd Edition. CRC Press, USA, 2004.

[4]. O.E. Udu-Ibiam, O. Ogbu, O. Nworie, U. A. Ibiam, M. V. Agah, A. U. Nnachi, K. I. Ogbu, Antimicrobial Activities of Some Selected Edible Mushrooms and Spices against Clinical Isolates from Federal University Teaching Hospital Abakaliki (FETHA), Ebonyi State, Nigeria, International Journal of Scientific and Technology Research, 3(5), 2014, 251-255.

[5]. Gull, M. Saeed, H. Shaukat, S. M. Aslam, Z. Q. Samra and A. M. Athar, Inhibitory Effect of Allium Sativum and Zingiber Officianale Extracts on Clinically Important Drug Resistant Pathogenic Bacteria, Annals of Clinical Microbiology and Antimicrobials, 11, 2012, 8.

[6]. N. Harsha, V. Sridevi, M.V.V. Chandana-Lakshmi, K. Rani, N. D. S. Vani, Phytochemical Analysis of Some Selected Spices, International Journal of Innovative Research in Science, Engineering and Technology, 2(11), 2013, 6618-6621.

[7]. S. Foster, Ginger Zingiber officinale - Your food is your medicine, 2011 [Online] Available from: http://www.stevenfoster.com/education/monograph/ginger.html.

[8]. P. Karuppiah and S. Rajaram. - Antibacterial effect of Allium sativum cloves and Zingiber officinale rhizomes against multipledrug resistant clinical pathogens, Asian Pac. J. Trop. Biomed., 2(8), 2012, 597-601. 
[9]. M. Sovova and P. Sovova. Pharmaceutical importance of Allium sativum L. hypopolipemic effects in vitro and in vivo in Czech. Ceska Slov Farm, 53(3), 2004, 117-123.

[10]. E. C. Egwim, R. C. Ellen and R. U. Egwuche, Proximate composition, phytochemical screening and antioxidant activity of ten selected edible mushrooms, American Journal of Food and Nutrition, 1(2), 2011, 89-94.

[11]. G. A. Otunola, O. B. Oloyede, A. T. Oladiji and A. J. Afolayan, Comparative analysis of the chemical composition of three spices - Allium sativum L. Zingiber officinale Rosc. and Capsicum frutescens L. commonly consumed in Nigeria, African Journal of Biotechnology, 9(41), 2010, 6927-6931.

[12]. R. U. Hamzah, A. A. Jigamu, H. M. Makun and E. C. Egwim, Phytochemical screening and antioxidant activity of methanolic extract of selected wild edible Nigerian mushrooms, Asian Pacific Journal of Tropical Disease, 4(1), 2014, S153-S157.

[13]. T. Mondal, R. Some and S. Dutta, Studies on antioxidant and antimicrobial properties of some common mushrooms, Journal of Today's Biological Sciences: Research \& Review (JTBSRR), 2(1), 2013, 60-67.

[14]. K. Manpreet, S. Giridhar and P. K. Khanna, "Invitro and in vivo antioxidant potentials of Pleurotus florida in experimental animals", Mushroom research, 13(1), 2004, 21-26.

[15]. B. Halliwell and J. Gutteridge, Free radicals in biology and medicine, 4th edition, Oxford, UK: Oxford University Press, 2007.

[16]. J. L. Mau, H. C. Lin, and C. C. Chen, Antioxidant properties of several medicinal mushrooms, Journal of Agricultural and Food Chemistry 50(21), 2002, 6072-6077.

[17]. Rahman, M. M. Rahman, M. M. I. Sheik, M. M. Rahman, S. M. Shadli and M. F. Alam, Free radical scavenging activity and phenolic content of Cassia sophera L., Afr J Biotechnol,7(10), 2008, 1591-1593.

[18]. L. Barros, M. J. Ferreira, B. Queiros, I. C. F. R. Ferreira and P. Baptista, Total phenols, ascorbic acid, $\beta$-carotene and lycopene in Portuguese wild edible mushrooms and their antioxidant activities. Food Chemistry 103, 2007, 413-419.

[19]. L. K. Jagadish, V. V. Krishnan, R. Shenbhagaraman and V. Kaviyarasan, Comparitive study on the antioxidant, anticancer and antimicrobial property of Agaricus bisporus (J. E. Lange) Imbach before and after boiling", African Journal of Biotechnology, 8(4), 2009, 654-661.

[20]. A. Olajire and L. Azeez, Total antioxidant activity, phenolic, flavonoid and ascorbic acid contents of Nigerian vegetables, African Journal of Food Science and Technology 2(2), 2011, 022-029.

[21]. O. Fasidi and S. G. Jonathan, Growth requirement of V. esculenta (Mss) Singer, a Nigerian edible mushroom, Chem. Mikfoldtednol.lednoson, 516, 1994, 151-155.

[22]. J. B. Harborne, Phytochemical methods: a guide to modern technique on plant analysis, Chapman and Hall, London, 1980, 302.

[23]. J. A. Maga, Phytate, its chemistry occurrence, food interaction nutritional significance and method of analysis, Journal of sciences and Agriculture, 1982, 30-31.

[24]. J. H. Brunner, Direct spectrophotometer determination of Saponin: analytical Chemistry, Cunnings publishing company, London, $1984,1314-1326$.

[25]. C. Chang, Y. Mang-Hua, W. Hwei-mei and Jing- chuan, Estimation of total flavonoid content in propolis by two complementary colometric methods, Journal of food and Drugs Analysis, 10(3), 2002, 178-182.

[26]. V. Panpatil, S. Tattari, N. Kota, C. Nimgulkar and K. Polasa, In vitro evaluation on antioxidant and antimicrobial activity of spice extracts of ginger, turmeric and garlic, Journal of Pharmacognosy and Phytochemistry, 2(3), 2013, 143-148.

[27]. H. O. Ehssan and A. M. Saadabi, Screening of antimicrobial activity of wild mushrooms from Khartoum State of Sudan. Microbiol J, 2(1), 2012, 64-69.

[28]. T. W. Wandati, G. M. Kenji and J. M. Onguso, Phytochemicals in edible wild mushrooms from selected areas in Kenya, Journal of Food Research, 2(3), 2013, 137.

[29]. B. A. Iwalokun, U. A. Usen, A. A. Otunba and D. K. Olukoya, Comparative phytochemical evaluation, antimicrobial and antioxidant properties of Pleurotus ostreatus, African Journal of Biotechnology, 6(15),2007, 1732-1739.

[30]. P. Mattila, K. Konko, M. Eurola, J. M. Pihlava, J. Astola, L. Vahteristo, V. Hietaniemi, J. Kumpulainen, M. Valtonen and V. Piironen, Contents of vitamins, mineral elements, and some phenolic compounds in cultivated mushrooms, J. Agric. Food Chem. 49, 2001, 2343-2348.

[31]. L. P. Xie, O. X. Chen, H. Huang, H. H. Wang and R. Q. Zhang, Inhibitory effects of some flavonoids on the activity of mushroom tyrosinase, Biochemistry (Mosc), 68(1), 2003, 487-491.

[32]. R. U. Hamzah, Egwim EC, Kabiru AY, Muazu MB. Phytochemical and in vitro antioxidant properties of the methanolic extract of fruits of Blighia sapida, Vitellaria paradoxa and Vitex doniana. Oxid Antioxid Med Sci 2013; 2(3): 215-221

[33]. Nagavani, Y. Madhavi, R. D. Bhaskar, R. P. Koteswara and R. T. Raghava, Free radical scavenging activity and qualitative analysis of polyphenols by RP-HPLC in the flowers of Couroupita guianensis Abul. Electron J Environ Agric Food Chem, 9(9), 2010, 14711484 .

[34]. D. Menaga, P. U. Mahalingam, S. Rajakumar and P. M. Ayyasamy, Evaluation of Phytochemical Characteristics and Antimicrobial Activity of Pleurotus Florida Mushroom, Asian Journal of Pharmaceutical and Clinical Research, 5(4), 2012, 102-106.

[35]. S. Idris, G. I. Ndukwe, and C. F. Gimba, Preliminary phytochemical screening and antimicrobial activity of seed extracts of Persea Americana (Avocado pear). Bayero Journal of Pure and Applied Sciences. 2(1), 2009, 173-176.

[36]. Z. Atai, M. Arapour and M. Mohensi, Inhibitory effect of ginger extract on C. albicans. American journal of applied sciences.3, 2009, 10-12.

[37]. G. Schneider and J. Wolfling, Synthetic cardenolides and related compounds. Current Organic Compounds, 8, 2004, 14.

[38]. R. E. Schulte, and R. Raffaur, The healing forest: medicinal and toxic plants of the North West Amazon Portland R.F, Dioscorrides press, 1990, 32-36.

[39]. B. Dulger, C. C. Ergul and F. Gucin, Antimicrobial activity of the macrofungus Lepista nuda, Fitoterapia, 73, 2002, 695-697.

[40]. H. Westerndarp, Effect of tannins in animal nutrition, Dtsch. Tierarztl. Wochenschn, 113(7), 2006, 264-268.

[41]. T. P. Anands and J. K. P. Edwards, Antimicrobial activity in the tissue extract of five species of cowries Cyprea spp. Mollusca: Gastropoda and an ascidian Didemnum Psammathodes Tunicata: Didemnidae, Indian Journal of marine sciences, 31(3), 2002, 239-242.

[42]. H. N. Bao, H. Ushio and M. Oshima, Anti oxidative activity and antidiscoloration efficacy of ergothionine in mushroom (Flammulina velupties) extract added to beef and fish meats', Journal of Agricultural and food chemistry, 56(21), 2008, 1003210040 .

[43]. A. Akindahunsi, Phytochemical Screening and Nutrient - Antinutrient Composition of Selected Green Leaf Vegetables, African Journal of Biotechnology, 4, 2005, 6 .

[44]. I. Das and T. Saha, Effect of garlic on lipid peroxidation and antioxidation enzymes in DMBA induced skin carcinoma Nutrition, $25(4), 2008,459-471$. 